\title{
Distribution of Adenovirus and Rotavirus by Age and Seasons in Children Diagnosed with Viral Gastroenteritis
}

\author{
Viral Gastroenterit Tanısı Alan Çocuklarda Adenovirüs ve Rotavirüslerin Yaşa ve Mevsimlere \\ Göre Dağılımları
}

\author{
(1) Yakup Çağ ${ }^{1}$, (1) Demet Hacıseyitoğlu ${ }^{2}$ \\ 1 University of Health Sciences Turkey, Kartal Dr. Lütfi Kırdar City Hospital, Clinic of Pediatrics, İstanbul, Turkey \\ 2Zonguldak Karaelmas University Faculty of Medicine, Department of Medical Microbiology, Zonguldak, Turkey
}

\section{Abstract}

Introduction: This study aimed to analyze the distribution of rotavirus and adenovirus in pediatric patients according to the age and seasons of infection. The study included pediatric patients who presented to our center and were investigated for fecal rotavirus and adenovirus with a prediagnosis of viral gastroenteritis.

Materials and Methods: The data of 7,841 patients, aged 0-13 years, who were diagnosed with acute gastroenteritis and were investigated for fecal rotavirus and adenovirus between January 2018 and July 2019 in the pediatric emergency, outpatient clinics, and inpatient services of our hospital, were retrospectively reviewed from the hospital database. The distribution of viruses, isolated according to the age groups and months and years, was analyzed statistically according to these age groups and seasons of infection.

Results: Of 7,714 patients, rotavirus or adenovirus was detected in 2,582 (33.5\%) patients: adenovirus was detected in 1,473 (19.1\%) patients; rotavirus was detected in 1,109 $(14.4 \%)$ patients $(p<0.05)$. Adenovirus was detected more frequently in the zero-to-one age group and rotavirus, in the one-to-six age group $(p<0.05)$. Adenovirus was detected more frequently in autumn and summer $(p<0.05) .70 .3 \%$ of patients with adenovirus or rotavirus were children in the zero-to-two age group.

Conclusion: In our study, we found that adenoviruses are the more common cause of viral gastroenteritis compared with rotaviruses. We determined that approximately $70 \%$ of patients with adenovirus or rotavirus are children in the zero-to-two age group.

Keywords: Gastroenteritis, child, rotavirus, adenovirus

\section{Öz}

Giriş: Merkezimize başvuran viral gastroenterit ön tanısıyla gaitada rotavirüs ve adenovirüs araştırılan çocuk hastalarda bu etkenlerin yaşa ve mevsimlere göre dağılımlarının analiz edilmesi amaçlanmıştır.

Gereç ve Yöntem: Hastanemizin çocuk acil, poliklinikler ve yataklı servislerinde Ocak 2018-Temmuz 2019 tarihleri arasında akut gastroenterit tanısı alan ve gaitada rotavirüs ve adenovirüs testi istenen 0-13 yaş arası 7.841 hasta verisi geriye dönük olarak hastane veri tabanından tarandı. Yaş grupları aylara ve yıllara göre gruplandırılarak izole edilen virüslerin bu yaş gruplarına ve mevsimlere göre dağılımları istatiksel olarak analiz edildi. Bulgular: 7.714 hastanın 2.582'sinde $(\% 33,5)$ rotavirüs veya adenovirüs tespit edildi. Olguların 1.473'ünde $(\% 19,1)$ adenovirüs, 1.109'unda $(\% 14,4)$ rotavirüs tespit edildi $(p<0,05)$. Adenovirüs $0-1$, rotavirüs 1-6 yaşları arasında daha sık görüldü $(p<0,05)$. Yaz ve sonbahar mevsiminde adenovirüs daha sık tespit edildi $(p<0,05)$. Adenovirüs veya rotavirüs tespit edilen olguların \%70,3'ü 0-2 yaş grubundaki çocuklar idi.

Sonuç: Çalışmamızda adenovirüslerin rotavirüslere göre daha sık viral gastroenterit etkeni olduğunu tespit ettik. Adenovirüs veya rotavirüs tespit edilen olguların yaklaşık \%70'inin 0-2 yaş grubundaki çocuklar olduğunu belirledik.

Anahtar Kelimeler: Gastroenterit, çocuk, rotavirüs, adenovirüs

Cite this article as: Çağ Y, Hacıseyitoğlu D. Distribution of Adenovirus and Rotavirus by Age and Seasons in Children Diagnosed with Viral Gastroenteritis. Mediterr J Infect Microb Antimicrob 2021;10:32.

Address for Correspondence/Yazışma Adresi: Yakup Çağ MD, University of Health Sciences Turkey, Kartal Dr. Lütfi Kırdar City Hospital, Clinic of Pediatrics, İstanbul, Turkey

Phone: +90 2164413900 E-mail: yakupcag@hotmail.com ORCID ID: orcid.org/0000-0002-3855-7280

Received/Geliş Tarihi: 09.03.2021 Accepted/Kabul Tarihi: 15.05.2021

o Copyright 2021 by the Infectious Diseases and Clinical Microbiology Specialty Society of Turkey

Mediterranean Journal of Infection, Microbes and Antimicrobials published by Galenos Yayinevi.
Presented in: This study was presented previously as an abstract in the BUHASDER congress held on October 16-20, 2019, Izmir, Turkey.

Published: 18 May 2021 


\section{Introduction}

Acute gastroenteritis is one of the most common diseases in humans and continues to be a major cause of morbidity and mortality worldwide ${ }^{[1]}$ Worldwide, around 525,000 children under the age of five die each year from diarrhea ${ }^{[2]}$. In countries with low income, diarrhea is the second leading cause of death in this age group ${ }^{[3]}$.

The incidence of gastroenteritis varies between countries and regions due to factors such as socioeconomic and nutritional status, access to safe water sources, wastewater disposal, food safety, electricity supply, food cooling, and close contact with animals ${ }^{[4]}$.

Viruses are the most common cause of acute gastroenteritis. The most common viruses causing acute gastroenteritis are rotavirus, norovirus, astrovirus, and human adenovirus types 40 and $41^{[5]}$. Generally, viruses are transmitted through direct person-to-person contact or indirectly through aerosols, food, water, or environmental pollution ${ }^{[6]}$.

Although acute gastroenteritis caused by viruses is normally self-limiting and results in a mild clinical picture, it may show a more severe clinical course in children, elderly, and immunocompromised individuals $s^{[7]}$.

Rotavirus is undoubtedly the most common cause of hospitalizations due to diarrhea in infants and children. Before the availability of vaccine, rotavirus was responsible for the death of almost $37 \%$ of infants and children due to diarrhea ${ }^{[3]}$. Rotavirus is more common in warm and tropical climates and in winter, and the clinical picture can range from being asymptomatic to having severe gastroenteritis, which can cause severe dehydration and death ${ }^{[8]}$. There is no specific antiviral drug that can be used in treating viral gastroenteritis yet. Treatment is limited to oral rehydration salts, fluid replacement, and supportive therapy.

Since these viruses are frequently found in the stools of symptomatic patients, electron microscopy and molecular methods can help in early diagnosi[s ${ }^{[3]}$

This study aimed to analyze the distribution of adenovirus and rotavirus in pediatric patients according to the age and seasons of infection. The study included pediatric patients who presented to our center and were investigated for fecal rotavirus and adenovirus with a prediagnosis of viral gastroenteritis.

\section{Materials and Methods}

The Study Design

The ethical committee of the University of Health Sciences Turkey, Kartal Dr. Lütfi Kırdar City Hospital, approved our study (decision number: 2019/514/167/26; dated: 12.06.2019). The study followed the principles of the Declaration of Helsinki. Informed parental consent was not obtained due to the retrospective nature of the study, and we used the patients' electronic data without ID information. For "each" retrospective study, written informed patient/parental consent was waived by our institution review board.

The data of 7,841 patients, aged 0-13 years who were diagnosed with acute gastroenteritis and were investigated for fecal rotavirus and adenovirus between January 2018 and July 2019 in the pediatric emergency, outpatient clinics, and inpatient services of our hospital, were retrospectively reviewed from the hospital database.

In the study, 127 patients were excluded due to inappropriate samples, and the test results of the remaining patients were examined.

Approximately 1-2 $\mathrm{ml}$ of fresh stool samples were sent immediately after collection to the microbiology laboratory in sealed sterile containers. An immunochromatographic test kit (ICA) (Ameritech Diagnostic Reagent Co., Ltd, One Step RotaAdenovirus Combo Panel Test, China) was used to detect adenovirus and rotavirus antigen in stool samples.

\section{Data Collection}

The demographic data, such as age and gender, of 2,582 patients with rotavirus or adenovirus, and their hospital admission dates were recorded in an Excel file. The distribution of viruses, isolated according to the age group and months and years, was analyzed according to these age groups and seasons of infection.

\section{Statistical Analysis}

All data were recorded in Excel spreadsheets and processed using the Statistical Package for the Social Sciences 20.0 software. For descriptive analysis, continuous variables were expressed as median and the first and third quartiles [interquartile range $(\mathrm{IOR})]$ when not normally distributed. Categorical variables were expressed as numbers and percentages and compared using the chi-squared test. A $p$ value less than 0.05 was considered significant.

\section{Results}

Of 7,714 patients whose adenovirus and rotavirus tests were studied with the diagnosis of gastroenteritis, $57 \%$ were males. Rotavirus or adenovirus was detected in 2,582 (33.5\%) patients. Adenovirus was detected in 1,473 (19.1\%) patients, and rotavirus was detected in 1,109 (14.4\%) patients.

\section{Distribution of Viruses by Age}

The median age distribution of patients with rotavirus was 17 (9-36) months and of patients with adenovirus (IQR) was 10 (425) months (Table 1). 
Table 1. Distribution of the age groups of children with rotavirus and adenovirus by months

\begin{tabular}{l|l|l|l|l|l|l|l|l|l|l|l}
\hline Age (month) & $0-3$ & $3-6$ & $6-12$ & $12-24$ & $24-36$ & $36-48$ & $48-60$ & $60-72$ & $72-84$ & $>84$ & Total \\
\hline $\begin{array}{l}\text { Rotavirus } \\
\mathrm{N}(\%)\end{array}$ & $72(2.8)$ & $85(3.3)$ & $233(9.0)$ & $308(11.9)$ & $139(5.4)$ & $74(2.9)$ & $65(2.5)$ & $62(2.4)$ & $25(1.0)$ & $46(1.8)$ & $1109(43.0)$ \\
\hline $\begin{array}{l}\text { Adenovirus } \\
\mathrm{N}(\%)\end{array}$ & $287(11.1)$ & $221(8.6)$ & $344(13.3)$ & $265(10.3)$ & $120(4.6)$ & $69(2.7)$ & $49(1.9)$ & $39(1.5)$ & $34(1.3)$ & $45(1.7)$ & $1473(57.0)$ \\
\hline Total N (\%) & $359(13.9)$ & $306(11.9)$ & $577(22.3)$ & $573(22.2)$ & $259(10.0)$ & $143(5.6)$ & $114(4.4)$ & $101(3.9)$ & $59(2.3)$ & $91(3.5)$ & $2582(100)$ \\
\end{tabular}

When the patients proven to have the viruses were analyzed by age, it was found that $70.3 \%$ of the patients with positive results were in the zero-to-two age range. After the age of two, it was observed that the frequency of both viruses decreased with increase of age. It was observed that adenovirus (33\%) was detected in the zero-to-one age group, and rotavirus (25.1\%) was detected in the one-to-six age group $(p<0.05)$ (Table 2).

\section{Distribution of Viruses by Seasons}

Considering the seasonal distribution, it was observed that both viruses were more common in winter and spring (rotavirus: $51.1 \%$ and 50.3\%; adenovirus: $49.9 \%$ and $49.7 \%$, respectively) compared with other seasons. The adenovirus was observed to be a more common cause of gastroenteritis than rotavirus in summer and autumn. The frequency of adenovirus was $73.9 \%$ in summer and $68.5 \%$ in autumn, that of rotavirus frequency was $26.1 \%$ in summer and $31.5 \%$ autumn. Adenovirus was detected more frequently in autumn and summer than rotavirus $(p<0.05)$ (Table 3).

\section{Discussion}

This study aimed to investigate the distribution of rotavirus and adenovirus in the stool of patients with a prediagnosis of

Table 2. Distribution of the age groups of children with rotavirus and adenovirus by years

\begin{tabular}{l|l|l|l|l}
\hline Age range (years) & $\begin{array}{l}\text { Rotavirus } \\
\text { N (\%) }\end{array}$ & $\begin{array}{l}\text { Adenovirus } \\
\text { N (\%) }\end{array}$ & $\begin{array}{l}\text { Total } \\
\text { N }\end{array}$ & $\mathbf{p}$ \\
\hline $0-1$ & $390(31.4)$ & $852(68.6)$ & 1242 & $<0.0001$ \\
\hline $1-2$ & $308(53.8)$ & $265(46.2)$ & 573 & 0.0101 \\
\hline $2-6$ & $340(55.1)$ & $277(44.9)$ & 617 & 0.0003 \\
\hline $6-13$ & $71(47.3)$ & $79(52.6)$ & 150 & 0.3594 \\
\hline Total N (\%) & $1109(43)$ & $1473(57)$ & 2582 & $<0.0001$
\end{tabular}

Table 3. Seasonal distribution of rotavirus and adenovirus agents detected in children

\begin{tabular}{l|l|l|l|l}
\hline Season & $\begin{array}{l}\text { Rotavirus } \\
\text { N (\%) }\end{array}$ & $\begin{array}{l}\text { Adenovirus } \\
\text { N (\%) }\end{array}$ & $\begin{array}{l}\text { Total } \\
\text { N }\end{array}$ & p \\
\hline Winter & $347(51.1)$ & $332(49.9)$ & 679 & 0.6584 \\
\hline Spring & $516(50.3)$ & $509(49.7)$ & 1025 & 0.7859 \\
\hline Summer & $147(26.1)$ & $417(73.9)$ & 564 & $<0.0001$ \\
\hline Autumn & $99(31.5)$ & $215(68.5)$ & 314 & $<0.0001$ \\
\hline Total N (\%) & $1109(43)$ & $1473(57)$ & 2582 & $<0.0001$
\end{tabular}

viral gastroenteritis according to the age groups and seasons of infection. Adenoviruses were detected more frequently than rotaviruses (14.4\%), with a frequency of 19.1\%. It was observed that one of these viruses was responsible for infecting 33.5\% of all children presenting with acute gastroenteritis clinic. Additionally, it was determined that these viruses are more common in the zero-to-two age group, especially in winter and spring.

The severity of acute gastroenteritis in childhood varies according to the age, season of infection, and geographical region ${ }^{[0]}$. In acute gastroenteritis, determining the viral and bacterial factors and predicting the prognosis are important in treatment and follow-up, which will avoid the use of unnecessary antibiotics.

In similar studies conducted in Turkey, rotavirus ranked first with a frequency of $8.1-23.6 \%$, and adenovirus ranked second with a frequency of $1.8-7.6 \% 0^{[10-14]}$. In a study involving 200 children in the United Kingdom, the frequency of rotavirus was $19 \%$, and the frequency of adenovirus was $5 \% \%^{[1]}$. In another study involving 510 pediatric patients in Italy, the frequency of rotavirus was $35.1 \%$, and the frequency of adenovirus was $23.1 \%{ }^{[15]}$ In a meta-analysis study involving children under the age of five in Africa, rotavirus and adenovirus caused gastroenteritis with a frequency of $29.2 \%$ and $10.8 \%$, respectively ${ }^{[16]}$. In our study, adenovirus was detected in 19.1\% of the patients and rotavirus in $14.4 \%$. We saw a significantly increased frequency of adenovirus compared with other studies. The clinical course of rotavirus-induced gastroenteritis is known to be more severe ${ }^{[17]}$. It is a possibility in other studies that more samples were taken from severely infected patients, and therefore, rotavirus was more isolated. Another reason could be that the rotavirus vaccine is increasingly being administered to children. However, we do not know the exact effect of this situation, since we do not have data on the rate of patients who received the rotavirus vaccine and were included in the study.

Other studies analyzed the distribution of rotavirus and adenovirus in pediatric patients according to the age groups. The results of these studies showed that, in children aged 12-24 months, rotavirus was the most commonly detected, similar to our study $y^{[9,12,13]}$.

While gastroenteritis caused by rotavirus was mostly seen in warm climates in winter and spring, it has been stated that 
adenovirus-induced gastroenteritis did not differ according to season $^{[10]}$. In our study, rotavirus was seen especially in winter and spring and adenovirus was present in all seasons. However, adenovirus was seen more frequently in summer and autumn compared with rotaviruses.

Simple hygiene practices, control of food and water, and proper waste disposal and sewage treatment will reduce the number of gastroenteritis cases and deaths ${ }^{[18]}$. Alternatively, the administration of rotavirus vaccine also reduces mortality and morbidity associated with gastroenteritis in children. Studies have shown that, after the rotavirus vaccine administration, hospitalizations of patients with diarrhea caused by rotavirus decreased to $63 \%$ from $94 \%{ }^{[19]}$.

It is crucial to make a correct and rapid diagnosis in children with gastroenteritis to start early treatment. The ICA shows a good agreement with enzyme-linked immunosorbent assay, enzyme-linked fluourescent assay, real-time polymerase chain reaction (PCR), and multiplex reverse transcription-PCR detection methodologies. Immunochromatographic assay has the advantage of being quicker, cost-effective, and useful for testing single specimen, convenient, not requiring additional equipment, readily available, simple to perform, and providing easy-to-read results ${ }^{[20,21]}$. Therefore, ICA could be useful in clinical practice for the rapid detection of rotavirus and adenovirus infection.

The limitation of our study is that single-center data were reviewed, including specific region's data and not representing the whole country.

\section{Conclusion}

In conclusion, we found that adenovirus causes viral gastroenteritis more commonly than rotavirus. We determined that approximately $70 \%$ of patients with adenovirus or rotavirus are children in the zero-to-two age group.

\section{Ethics}

Ethics Committee Approval: The Ethical Committee of the University of Health Sciences Turkey, Kartal Dr. Lütfi Kırdar City Hospital, approved our study (decision number: 2019/514/167/26; dated: 12.06.2019).

Informed Consent: Retrospective study.

Peer-review: Externally peer-reviewed.

\section{Authorship Contributions}

Surgical and Medical Practices: Y.Ç., D.H., Concept: Y.Ç., Design: Y.Ç., D.H., Data Collection or Processing: Y.Ç., D.H., Analysis or Interpretation: Y.Ç., D.H., Literature Search: Y.Ç., Writing:Y.Ç., D.H.
Conflict of Interest: No conflict of interest was declared by the authors.

Financial Disclosure: The authors declared that this study received no financial support.

\section{References}

1. Borrows CL, Turner PC. Seasonal screening for viral gastroenteritis in young children and elderly hospitalized patients: is it worthwhile? J Hosp Infect. 2014;87:98-102.

2. Quintero-Ochoa $G$, Romero-Argüelles $R$, Aviles-Hernández $A$, Cejudo-Flores $\mathrm{M}$, Calleja-Garcia P, Domínguez-Gámez M, Cantú-Bernal S, Icedo-Garcia $\mathrm{R}$, Soñanez-Organis J, Rosas-Rodríguez J, Romo-Saenz C, Tamez-Guerra P, Flores-Mendoza L, González-Ochoa G. Viral agents of gastroenteritis and their correlation with clinical symptoms in rotavirus-vaccinated children. Infect Genet Evol. 2019;73:190-6.

3. Iturriza Gómara $M$, Cunliffe NA.Viral gastroenteritis. In: Ryan Edward $T$ Hill David R, Solomon T, Aronson Naomi E, Endy Timothy P (ed). Hunter's Tropical Medicine and Emerging Infectious Diseases. $10^{\text {st }}$ ed. London: Elsevier; 2020:289-307.

4. PeiranoV,Bianco MN, Navarro A, Schelotto F,Varela G. Diarrheagenic Escherichia coli associated with acute gastroenteritis in children from Soriano, Uruguay. Can J Infect Dis Med Microbiol. 2018;2018:8387218.

5. Tran A, Talmud D, Lejeune B, Jovenin N, Renois F, Payan C, Leveque N, Andreoletti L. Prevalence of rotavirus, adenovirus, norovirus, and astrovirus infections and coinfections among hospitalized children in northern France. J Clin Microbiol. 2010;48:1943-6.

6. Hebbelstrup Jensen B, Jokelainen P, Nielsen ACY, Franck KT, Rejkjær Holm D, Schønning K, Petersen AM, Krogfelt KA. Children Attending Day Care Centers are a Year-round Reservoir of Gastrointestinal Viruses. Sci Rep. 2019;9:3286.

7. Bassetto M, Van Dycke J, Neyts J, Brancale A, Rocha-Pereira J. Targeting the Viral Polymerase of Diarrhea-Causing Viruses as a Strategy to Develop a Single Broad-Spectrum Antiviral Therapy. Viruses. 2019;11:173.

8. Köse $\mathrm{H}$, Temoçin F.Akut Gastroenteritli Çocuklarda Adenovirüs ve Rotavirüs Sıklığııın Araştırııması. Flora. 2019;24:22-6.

9. Topal i. Bir Eğitim Hastanesinde Pediatrik Hastalarda Gastroenterit Etkenlerinin Değerlendirilmesi. Kocatepe Tıp Dergisi. 2019;20:188-94.

10. Tüzüner U, Gülcen BS, Özdemir M, Feyzioğlu B.Gastroenteritli çocukların dışkılarında adenovirus ve rotavirus sıklığı ve mevsimsel dağılımı. Klimik Dergisi. 2016;29:121-4.

11. Terzi HA, Aydemir Ö. Akut Gastroenteritli Hastalarda Rotavirüs ve Adenovirüs Sıklığının Araştııılması; Sakarya. Sakarya Tıp Dergisi. 2018;8:746-52.

12. Çaycı YT, Yılmaz G, Birinci A. Akut gastroenterit vakalarında rotavirüs ve adenovirüs sıklığının araştırılması. Pamukkale Tıp Dergisi. 2017;10:61-5.

13. Coşkun USŞ, Kasap T. Frequency of rotavirus and adenovirus in pediatric patients with acute gastroenteritis. J Contemp Med. 2019;9:85-8.

14. Tekin M, Topaloğlu N, Yıldııım Ş, Binnetoğlu K, Kaymaz N, Aylanç H, Battal F Vural A, Başer E. Akut gastroenteritli çocuklarda rotavirüs sıklığı. Uluslararası Klinik Araştırmalar Dergisi. 2014;2:18-20.

15. Biscaro V, Piccinelli G, Gargiulo F, laniro G, Caruso A, Caccuri F, De Francesco MA. Detection and molecular characterization of enteric viruses in children with acute gastroenteritis in Northern Italy. Infect Genet Evol. 2018;60:3541.

16. Oppong TB, Yang $\mathrm{H}$, Amponsem-Boateng $\mathrm{C}$, Kyere EKD, Abdulai T, Duan $\mathrm{G}$, Opolot $\mathrm{G}$. Enteric pathogens associated with gastroenteritis among children under 5 years in sub-Saharan Africa: a systematic review and meta-analysis. Epidemiol Infect. 2020;148:e64. 
17. Posovszky C, Buderus S, Classen M, Lawrenz B, Keller KM, Koletzko S. Acute Infectious Gastroenteritis in Infancy and Childhood. Dtsch Arztebl Int. 2020;117:615-24.

18. Pratte-Santos R, Miagostovich MP, Fumian TM, Maciel EL, Martins SA, Cassini ST, Keller R. High prevalence of enteric viruses associated with acute gastroenteritis in pediatric patients in a low-income area in Vitória, Southeastern Brazil. J Med Virol. 2019;91:744-50.

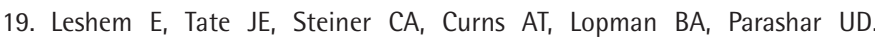
Acute gastroenteritis hospitalizations among US children following implementation of the rotavirus vaccine. JAMA. 2015;313:2282-4.
20. Kim J, Kim HS, Kim HS, Kim JS, Song W, Lee KM, Lee S, Park KU, Lee W, Hong YJ. Evaluation of an immunochromatographic assay for the rapid and simultaneous detection of rotavirus and adenovirus in stool samples. Ann Lab Med. 2014;34:216-22.

21. Ozsari T, Bora G, Kaya B, Yakut K. The Prevalence of Rotavirus and Adenovirus in the Childhood Gastroenteritis. Jundishapur J Microbiol. 2016;9:e34867. 